\title{
PENGARUH PENERAPAN MODEL PEMBELAJARAN KOOPERATIF TIPE KARTU ARISAN TERHADAP HASIL BELAJAR DI SMA NEGERI 8 PALEMBANG
}

\author{
Oleh: Erma Yulaini ${ }^{1}$, Melisa Anggraini ${ }^{2}$ \\ ermayulaini074@gmail.com ${ }^{1}$, melisaanggraini353@gmail.com² \\ (Program Studi Pendidikan Akuntansi, FKIP Universitas PGRI Palembang)
}

\begin{abstract}
Abstrak-Tujuan penelitian ini adalah untuk mengetahui pengaruh model pembelajaran kooperatif tipe kartu arisan terhadap hasil belajar siswa di SMA Negeri 8 Palembang. Metode penelitian yang digunakan adalah metode eksperimen. Teknik pengumpulan data yang digunakan adalah dokumentasi observasi dan tes. Populasi dalam penelitian ini berjumlah 96 siswa, sedangkan sampel dalam penelitian ini berjumlah 64 siswa. Diketahui hasil belajar siswa kelas eksperimen nilai tertinggi adalah 95 dan terendah 60 dengan rata-rata 79,4, sedangkan kelas kontrol nilai tertinggi adalah 85 dan terendah 55 dengan rata-rata 71,6. Hasil penelitian menunjukkan bahwa $t_{\text {hitung }}=4,864>t_{\text {tabel }}=1,999$ , maka tolak Ho terima Ha dengan demikian terdapat pengaruh penggunaan model pembelajaran kooperatif tipe kartu arisan terhadap hasil belajar siswa di SMA Negeri 8 Palembang. Besarnya interpretasi pengaruh adalah sebesar 52\% sedangkan sisanya sebesar $48 \%$ dipengaruhi faktor lain.
\end{abstract}

Kata Kunci: Model pembelajaran, Kooperatif Tipe Kartu Arisan, Hasil belajar

\begin{abstract}
The purpose of this study was to determine the Effect of Cooperative Learning Model Type of social gathering cards on Student Learning Outcomes in SMA Negeri 8 Palembang. The research method used is experimental. Data collection techniques used were observation and test documentation. The population in this study amounted to 96 students, while the sample in this study amounted to 64 students. It is known that student learning outcomes of the experimental class the highest grades are 95 and the lowest is 60 with an average of 79.4, while the control class highest is 85 and the lowest is 55 with an average of 71.6. The results showed that count $=4,864>$ table $=1,999$, then reject Ho received $H \alpha$ thus there was an influence of the use of cooperative learning model type of social gathering cards on student learning outcomes in SMA Negeri 8 Palembang. The magnitude of the interpretation of influence is $52 \%$ while the remaining $48 \%$ is influenced by other factors.
\end{abstract}

Keywords: Learning model, Cooperative Type of Arisan Cards, Learning Outcomes

\section{PENDAHULUAN}

Pendidikan merupakan salah satu bagian terpenting dalam fase kehidupan manusia, untuk menjamin kelangsungan hidup berbangsa dan bernegara guna meningkatkan dan 
mengembangkan kualitas sumber daya manusia. serta mampu menghadapi tantangan globalisasi dalam mewujudkan masyarakat yang maju. Kemajuannya selalu ditentukan oleh kualitas pendidikan yang ada di negaranya. Pendidikan yang dimaksud disini adalah proses belajar mengajerar interaksi atau hubungan timbal balik antara guru dengan peserta didik. Untuk melakukan sebuah proses belajar, terlebih dahulu harus dipahami pengertian dari kata belajar dan mengajar.

Belajar merupakan proses yang dilakukan oleh peserta didik untuk memperoleh pengetahuan sedangkan mengajar merupakan salah satu potensi guru berupa penguasaan dan keterampilan dalam melaksanakan proses mengajar. Keberhasilan suatu proses belajar mengajar tidak terlepas dari suatu model pembelajaran yang dilakukan supaya sasaran yang dilakukan tercapai dengan baik, karena model pembelajaran merupakan alat untuk mencapai suatu tujuan. Untuk itu pendidik perlu memahami interaksi belajar mengajar selama proses belajar berlangsung dan sebaiknya dapat dipertahankan kualitasnya, sebab apabila hubungan interaksi tersebut tidak terjalin dengan baik maka mengakibatkan tujuan dari pembelajaran itu akan sulit tercapai.

Agar tujuan pembelajaran tercapai secara efektif, maka guru harus melakukan persiapan atau perencanaan pembelajaran, salah satunya menentukan model pembelajaran interaktif. Dengan menggunakan model pembelajaran interaktif tentunya diharapkan dapat mempengaruhi hasil belajar siswa.

"Menurut Irawan dkk (2019:100) hasil belajar merupakan suatu pencapaian yang diperoleh peserta didik dalam kegiatan belajar mengajar yang dilaksanakan oleh peserta didik tersebut dalam periode tertentu. Berdasarkan keadaan yang sering kita temukan bahwa di dalam proses belajar mengajar di sekolah siswa cenderung diam dan sulit mengungkapkan pendapatnya sehingga dalam pembelajaran kurang terjadi interaksi umpan balik antara guru dengan siswa yang menyebkan pemahamaan siswa menjadi kurang terhadap materi pelajaran yang disampaikan. Hal ini akan berdampak pada rendahnya hasil belajar siswa dalam proses pembelajaran tersebut. Permasalahan tersebut perlu segera diatasi salah satunya dengan cara menggunakan model pembelajaran yang dianggap tepat untuk meningkatkan hasil belajar siswa yaitu model pembelajaran kooperatif tipe kartu arisan.

Berdasarkan observasi awal yang dilakukan Peneliti. di SMA Negeri 8 Palembang selama 2 bulan terakhir ini proses belajar mengajar menggunakan metode ceramah, tanya jawab, dan diskusi dari metode tersebut diperoleh hasil pembelajaran 
yang baik tetapi masih belum optimal. Dikarenakan rendahnya motivasi belajar siswa pada mata pelajaran ekonomi serta rata-rata nilai yang diperoleh siswa belum pencapai KKM (Keriteria Ketuntasan Minimal) yang telah ditentukan guru mata pelajaran ekonomi. Maka dari itu peneliti berkeinginan untuk meneliti tentang model pembelajaran kooperatif tipe kartu arisan dengan harapan hasil belajar siswa akan lebih baik serta KKM (Keriteria Ketuntasan Minimal) meningkat.

Berdasarkan uraian permasalahan tersebut, peneliti berkeinginan untuk melakukan penelitian dengan judul "Pengaruh Penerapan Model Pembelajaran Kooperatif Tipe Kartu Arisan Terhadap Hasil Belajar Siswa di SMA Negeri 8 Palembang Tahun Ajaran 2019/2020".

Berdasarkan definisi latar belakang, maka rumusan masalah yang akan dibahas pada penelitian ini adalah: "Adakah pengaruh penerapan model pembelajaran kooperatif tipe kartu arisan terhadap hasil belajar siswa di SMA Negeri 8 Palembang Tahun Ajaran 2019/2020?".

Tujuan dari penelitian ini merupakan pernyataan mengenai ruang lingkup kegiatan yang akan dilakukan berdasarkan masalah yang telah dirumuskan. Adapun tujuan dari penelitian ini adalah untuk mengetahui pengaruh model pembelajaran kooperatif tipe kartu arisan terhadap hasil belajar siswa di
SMA Negeri 8 Palembang tahun pelajaran 2019/2020.

Menurut Priansa (2015:150) Model pembelajaran dapat dipahami sebagai kerangka konseptual yang melukiskan prosedur yang sistematis dan terencana dalam mengorganisasikan proses pembelajaran peserta didik sehingga tujuan pembelajaran dapat dicapai secara efektif.

Menurut Hanafiah (2017, dikutip dari jurnal Yulaini) "Model pembelajaran merupakan salah satu pendekatan dlam rangka mensiasati perubahan perilaku peserta didik secara adaptif maupun generatif. Model tersebut merupakan pola umum perilaku pembelajaran untuk mencapai tujuan pembelajaran yang diharapkan". (http://jurnal.univpgripalembang.ac.id/index.php/prosiding /article/download/1065) diakses pada tanggal 11 Oktober 2019 .

Menurut Trianto

(2011:53)

Model pembelajaran adalah kerangka konseptual yang melukiskan prosedur sistematik dalam mengorganisasikan pengalaman belajar untuk mencapai tujuan belajar tertentu dan berfungsi sebagai pedoman bagi perancang pembelajaran dan para guru dalam merancang dan melaksanakan pembelajaran.

Menurut Agus (2009, dikutip dari jurnal Januardi) "Model pembelajaran adalah landasan praktik pembelajaran hasil penurunan teori psikologi pendidikan 
dan teori belajar yang dirancang berdasarkan analisis tehadap implementasi kurikulum dan implikasinya pada tingkat operasional kelas". (http://journal2.um.ac.id/index.php/jp e/index) diakses pada tanggal 08 November 2019.

Jadi dapat ditarik kesimpulan bahwa model pembelajaran adalah suatu rencana acuan yang dipersiapkan untuk mencapai tujuan agar berjalan sesuai apa yang telah dirancang, baik dari segi bahan pembelajaran maupun cara membimbing pembelajaran di dalam kelas.

Ada beberapa kelompok model pembelajaran diantaranya dapat dikelompokan kedalam empat kategori, yakni Menurut Joyce \& Weli (dalam Parwati, dkk 2018:124).

1. Kelompok Model Pengelolahan Informasi atau "The Information Processing Family",

2. Kelompok Model Personal atau "The Personal Family".

3. Kelompok Model Sosial atau "The Social Family".

4. Kelompok Model Sistem Perilaku atau "The Behavioral System Family".

Model pembelajaran kartu arisan. Ini termasuk dalam kelompok model sosial atau The social Family merupakan model pelajaran yang membentuk kelompok kecil serta disusun dan direncanakan oleh guru pada mata pelajaran yang akan diajarkan. kelompok model sosial atau The social Family termasuk dalam model pembelajaran kooperatif.

Model pembelajaran kooperatif merupakan suatu model pembelajaran kelompok kecil yang memiliki tujuan yang sama. Ada beberapa definisi model pembelajaran kooperatif menurut beberapa para ahli sebagai berikut:

Menurut Alma, dkk (2012:85) Coopertive bearti bekerja sama dan learning bearti belajar, jadi belajar melalui kegiatan bersama. Namun tidak semua belajar bersama adalah cooperative learning, dalam hal ini belajar bersama melalui teknikteknik tertentu. Cooperative learning merupakan suatu model pembelajaran dengan menggunakan kelompok kecil, bekerja sama.

Menurut Hamdayama (2014:64) Model pembelajaran kooperatif merupakan model pembelajaran dengan menggunakan sistem pengelompokan / tim kecil, yaitu antara empat sampai enam orang yang memiliki latar belakang kemampuan akademik, jenis kelamin, ras atau suku yang berbeda.

Menurut Cruickshank (2014:3) Model pembelajaran kooperatif (baru-baru ini disebut dengan pembelajaran tim siswa) adalah istilah yang digunakan untuk mendeskripsikan prosedur instruksional di mana siswa bekerja sama dalam kelompok kecil dan diberikan hadiah untuk peraihan kolektif mereka. 
Jadi dapat di tarik kesimpulan bahwa model pembelajaran kooperatif adalah model pembelajaran dalam kelompok kecil yang di dalamnya terdiri dari 4 sampai 6 orang yang bekerja sama dalam sebuah tim berdasarkan prosedur yang ada di dalamnya untuk mencapai tujuan bersama.

Kartu arisan merupakan termasuk salah satu media perantara bagi siswa untuk memperoleh pengetahuan. Berikut pendapat dari beberapa para ahli mengenai kartu arisan yaitu:

Menurut Malalina (2018:843) tipe kartu arisan adalah salah satu model pembelajaran kooperatif yang sangat mudah pelaksanaanya dan sangat menyenangkan. Tipe kartu arisan adalah suatu model pembelajaran kooperatif yang memberikan kesempatan kepada siswa untuk bekerja sama di dalam kelompok kecil untuk berdiskusi mengenai jawaban dari setiap pertanyaan yang keluar dari dalam gelas yang telah diacak. Salah satu materi yang dapat menggunakan kertu arisan adalah materi belah ketupat dan layang-layang.

Menurut Sahputra, dkk (2017:94) Model tipe kartu arisan adalah salah satu pembelajaran kooperatif, dimana siswa bekerjasama dalam kelompok untuk mendiskusikan kesesuaian jawaban dari setiap pertanyaan yang keluar dari dalam gelas yang telah dikocok oleh guru. Strategi ini merupakan bentuk kerja sama antar kelompok yang di dalamnya sangat diperlukan komunikasi antar teman kelompoknya maupun dengan guru sebagai fasillitator.

Jadi dapat ditarik kesimpulannya bahwa tipe kartu arisan adalah pembelajaran yang menuntut setiap siswa aktif, guru akan mempersiapkan soal beserta jawabannya kemudian soal yang ada digulung menyerupai koncangan arisan. Ketika soal keluar dari koncangan, siswa yang memegang jawaban harus secepat mungkin menjawab dengan benar, bagi teman sekelompoknya harus selalu mengingatkan teman yang lain agar tidak terlambat dalam menjawabnya hal ini lah yang menimbulkan suasana yang menyenangkan serta menjaga kekompakan antar kelompok.

Menurut Uno (dalam Malalina, 2018:845) Adapun kelebihan dan kekurangan model pembelajaran kooperatif tipe kartu arisan sebagai berikut:

a. Kelebihan model kartu arisan yaitu pembelajaran yang menarik dihubungkan dengan kehidupan nyata.

b. Kekurangan model kartu arisan adalah tidak semua terlibat dalam kegiatan pembelajaran dan nilai tergantung pada individu yang mempengaruhi nilai teman lain. 
Adapun langkah-langkah model pembelajaran yang akan di lakukan dalam peneliti ini disesuaikan berdasarkan situasi, kondisi dan lokasi peneliti yaitu:

1. Terlebih dahulu peneliti menyiapkan kartu jawaban dengan ukuran 9x6 $\mathrm{cm}$ dan kertas soal dengan ukuran 9x6 $\mathrm{cm}$ pada mata pelajaran ekonomi materi konsep ilmu ekonomi.

2. Membentuk anggota tim yang terdiri dari 4 orang secara heterogen. Membagikan kartu jawaban yang telah disiapkan pada tiap-tiap siswa, masingmasing siswa mendapatkan satu kartu.

3. Kertas soal yang telah disiapkan kemudian digulung dan dimasukan ke dalam gelas oleh peneliti.

4. Gelas yang sudah berisi kertas soal selanjutnya dikocok, kemudian salah satu kertas soal yang jatuh, dibacakan oleh peneliti agar dijawab oleh siswa yang memegang kartu jawaban.

5. Apabila jawaban benar, maka siswa dipersilahkan tepuk tangan.

6. Setiap jawaban yang benar, siswa diberi 1 poin sebagai nilai kelompok sehingga nilai total kelompok merupakan penjumlahan poin dari para anggota timnya dan seterusya.

7. Peneliti melakukan perhitung perolehan poin dari tiap-tiap kelompok, menjumlahkannya dan mengumumkannya.

8. Peneliti melemparkan pertanyaan rebutan, apabila terdapat jumlah point yang sama pada dua anggota tim atau lebih.

9. Peneliti memberikan apresiasi kepada anggota tim yang memperoleh point paling banyak bisa berupa pujian, tepuk tangan, acungan jempol atau senyuman.

Untuk mendapatkan hasil belajar yang ingin dicapai ada baiknya terlebih dahulu kita harus mengetahui pengertian hasil belajar. Berikut pengertian hasil belajar menurut beberapa para ahli:

Menurut Hamalik (2006, dikutip dari jurnal Nova Pratiwi) "hasil belajar adalah bila seseorang telah belajar akan terjadi perubahan tingkah laku pada orang tersebut, misalnya dari tidak tahu menjadi tahu, dan dari tidak mengerti menjadi mengerti”.

(http://jurnal.univpgripalembang.ac.i

d) diakses pada tanggal 06 November 2019.

Menurut Jihad dan Haris (2013:14) Hasil belajar pencapaian bentuk perubahan perilaku yang cenderung menetap dari ranah kognitif, afektif, dan psikomotoris dari proses belajar yang dilakukan dalam waktu tertentu.

Hasil belajar adalah kemampuan-kemampuan yang dimiliki mahasiswa setelah ia menerima pengalaman belajarnya (Sudjana, 2009:22, dikutip dari jurnal 
Pramika dan Widalismana). Menurut Menurut Suprijono (2013:7) Hasil belajar adalah perubahan perilaku secara keseluruhan bukan hanya salah satu aspek potensi kemanusiaan saja.

"Hasil belajar yaitu sesuatu perubahan yang terjadi pada individu yang belajar, tetapi juga untuk membentuk kecakapan, kebiasaan, pengertian, penguasaan, dan penghargaan, dalam diri, seseorang yang belajar". Gunawan (2017:35). (https://Jurnal.univpgri-

palembang.ac.id) diakses pada tanggal 06 November 2019 pukul 16:50.

Jadi dapat disimpulkan bahwa hasil belajar merupakan suatu pencapaian berupa perilaku siswa terlihat dari aspek kognitif, afektif, dan psikomotor. Penguasaan terhadap materi pembelajaran yang disampaikan untuk mencapai suatu tujuan, Setelah melakukan kegiatan pembelajaran.

\section{HASIL DAN PEMBAHASAN}

Berdasarkan analisis observasi belajar siswa di kelas X IPS 3 selama kegiatan belajar mengajar dapat dilihat sebagai berikut:

Dapat diketahui bahwa sebagian besar siswa kelas eksperimen yang menggunakan model pembelajaran kooperatif tipe kartu arisan pada kriteria "Sangat Aktif" mencapai persentase sebesar $6,25 \%$ dengan jumlah siswa 2 orang. Siswa yang tergolong kriteria "Aktif" mencapai persentase sebesar $87,50 \%$ dengan jumlah siswa 28 orang, sedangkan siswa yang tergolong kriteria "Cukup Aktif" pada saat kegiatan belajar sebesar 6,25\% dengan jumlah siswa 2 orang. dan tidak ada siswa yang keaktifan belajarnya pada kriteria "Kurang Aktif, dan Sangat Kurang Aktif'. Rata-rata keaktifan belajar siswa pada kelas eksperimen sebesar 79,78 pada kriteria "Aktif".

Analisis data observasi digunakan untuk mengetahui keaktifan belajar dalam kelas. Distribusi frekuensi keaktifan hasil observasi kelas kontrol sebagai berikut:

Diketahui bahwa sebagian besar siswa kelas kontrol dengan menggunakan model pembelajaran konvensional yang tergolong dalam kriteria "Aktif" mencapai persentase sebesar $18,75 \%$ dengan jumlah siswa 6 orang, sedangkan siswa yang tergolong kriteria "Cukup Aktif" mencapai persentase sebesar $81,25 \%$ dengan jumlah siswa 26 orang, dan tidak ada yang memperoleh skor kriteria "Sangat Aktif, Kurang Aktif, dan Sangat Kurang Aktif". Rata-rata keaktifan belajar siswa pada kelas kontrol sebesar 67,96 pada kriteria "Cukup Aktif".

Penelitian ini telah dilaksanakan di SMA Negeri 8 Palembang. Waktu penelitian dilaksanakan tiga minggu mulai dari tanggal 25 juli 2019 sampai 8 agustus 2019. Siswa yang diteliti 
adalah siswa kelas X IPS 3 sebagai kelas eksperimen yaitu kelas yang diberi perlakuan dengan menggunakan model pembelajaran kooperatif tipe kartu arisan dengan jumlah siswa 32 orang. dan Kelas X IPS 1 sebagai kelas kontrolyaitu kelas yang menggunakan model pembelajaran konvensional dengan jumlah siswa 32 orang. Pada semester ganjil, tahun ajaran 2019/2020.

Analisis data hasil belajar siswa kelas X IPS 3 selama proses belajar mengajar sebagai berikut:

Dapat diketahui bahwa yang memperoleh nilai 86-100 sebesar $6,25 \%$ pada keriteria "Baik Sekali" berjumlah 2 orang siswa, yang memperoleh nilai dengan kriteria "Baik" sebesar $87,50 \%$ berjumlah 28 orang siswa, dan yang memperoleh nilai "Cukup" sebesar 6,25\% berjumlah 2 orang siswa. Rata-rata hasil belajar siswa kelas eksperimen adalah 79,4.

Analisis data hasil belajar siswa kelas X IPS 1 selama proses belajar mengajar sebagai berikut:

Dapat diketahui bahwa yang memperoleh nilai 71-85 sebesar $43,75 \%$ dengan kriteria "Baik" berjumlah 14 orang siswa, yang memperoleh nilai 56-70 dengan kriteria "Cukup" sebesar 53,125\% berjumlah 17 orang siswa, dan yang memperoleh nilai 41-55 sebesar $3,125 \%$ berjumlah 1 orang siswa. Rata-rata hasil belajar siswa kelas kontrol adalah 71,6.
Dari hasil perhitungan tersebut diperoleh $t_{\text {hitung }}>t_{\text {tabel }}$ atau 4,864>1,999 bearti dapat disimpulkan bahwa tolak $\mathrm{H}_{\mathrm{o}}$ dan terima $\mathrm{H}_{\mathrm{a}}$ maka hipotesis penelitian berbunyi ada pengaruh penggunaan model pembelajaran kooperatif tipe kartu arisan terhadap hasil belajar siswa pada mata pelajaran ekonomi kelas X IPS 3 di SMA Negeri 8 Palembang tahun pelajaran 2019/2020. Diterima dengan pengaruh sebesar $27,6 \%$ dengan kategori "Rendah". Sedangkan koefisien korelasi sebesar 52\% pada kriteria sedang.

Berdasarkan hal tersebut maka senada dengan pendapat Ricki Maulizar Sahputra, dkk (2017) yang menyatakan ada pengaruh penerapan model pembelajaran tipe kartu arisan untuk meningkatkan hasil belajar siswa kelas XI IS SMA Negeri 7 Banda Aceh. hasil penelitian ini menunjukan bahwa (1) persentase ketuntasan secara individual meningkat dari 20 siswa yang tuntas pada siklus1,25 siswa tuntas pada siklus II, dan 30 tuntas pada siklus III, persentase ketuntasan klasikal pun meningkat dari $60 \%$ pada siklus I, $80 \%$ pada siklus II, dan $90 \%$ pada siklus III; (2) aktivitas guru dan guru meningkat menjadi sesuai dengan persentase wktu ideal; (3) keterampilan guru meningkat dari perolehan skor 2,5 pada siklus I dengan kategori sedang, skor 3,1 pada siklus II dengan kategori baik, dan 3,4 pada siklus III dengan 
kategori baik; (4) respon siswa, terhadap model pembelajaran kooperatif tipe kartu arisan dapat dikatakan baik. 95 persen dari 32 siswa terdapat bahwa dengan belajar melalui model pembelajaran kooperatif tipe kartu arisan dapat meningkatkan pemahaman mereka terhadap materi yang telah dipelajari.

Menurut Yulaini, (2017) dapat disimpulkan bahwa model pembelajaran make-A Match adalah salah satu pembelajaran kooperatif dengan mencari pasangan digunakan untuk memahami suatu konsep atau informasi tertentu yang harus ditemukan peserta didik. Tujuannya agar peserta didik dapat memahami konsep-konsep dasar akuntansi sehingga diharapkan kejenuhan dan kesulitan terhadap mata pelajaran akuntansi bisa teratasi dan hasil belajar siswa menjadi lebih meningkat sesuai standar ketuntasan minimal (KKM).

Selain itu juga sejalan dengan pendapat Ernayetti (2018) yang menyatakan terdapat pengaruh model pembelajaran kartu arisan dapat meningkatkan hasil belajar peserta didik pada pokok bahasan program linier di kelas XI MIA 2 SMA Negeri 2 Pekanbaru" hasil penelitian ini menunjukan bahwa penerapan model pembelajaran kartu arisan dapat meningkatkan hasil belajar siswa dengan persentase pada siklus I sebesar 75,42\%, siklus II sebesar $78,28 \%$, dan siklus III sebesar $83,71 \%$.
Hasil analisis dalam penelitian ini menunjukkan bahwa terdapat pengaruh model pembelajaran kooperatif tipe kertu arisan terhadap hasil belajar siswa pada mata pelajaran ekonomi di SMA Negeri 8 Palembang. Hasil perhitungan hasil belajar siswa yang diperoleh dari nilai tes diperoleh nilai tertinggi pada kelas eksperimen yaitu sebesar 95 dan yang terendah 60, diperoleh rata-rata hasil belajar siswa sebesar 79,4. Terdapat 2 siswa dengan persentase $6,25 \%$ pada kriteria "Baik Sekali", 28 siswa dengan persentase $87,50 \%$ pada kriteria "Baik" dan 2 siswa dengan persentase $6,25 \%$ pada kriteria "Cukup". Sedangkan nilai tertinggi pada kelas kontrol yaitu 85 dan yang terendah 55, diperoleh rata-rata sebesar 71,6. Terdapat 14 siswa dengan persentase $43,75 \%$ pada kriteria "Baik", terdapat 17 dengan persentase $53,13 \%$ pada kriteria "Cukup", dan terdapat 1 siswa dengan persentase $3,12 \%$ pada kriteria "Kurang".

Penelitian menggunakan rumus uji t dengan hasil perhitungan diperoleh harga $t_{\text {hitung }}=4,864>$ dari $t_{\text {tabel }}=1,999$ berarti tolak Ho dan terima $\mathrm{H} \alpha$ maka terdapat pengaruh penggunaan model pembelajaran kooperatif tipe kartu arisan terhadap hasil belajar siswa di SMA Negeri 8 Palembang. yaitu sebesar $52 \%$ sedangkan sisanya sebesar 48 dipengaruhi faktor lain. 
Dari uraian di atas maka dapat dartikan bahwa menerapkan model pembelajaran kooperatif tipe kartu arisan dapat meningkatkan hasil belajar siswa.

\section{KESIMPULAN}

Hasil penelitian menunjukan bahwa $t_{\text {hitung }}>t_{\text {tabel }}$ atau 4,864 $>1,999$, maka tolak $\mathrm{H}_{\mathrm{o}}$ dan terima $\mathrm{H}_{\mathrm{a}}$ bearti dapat disimpulkan ada pengaruh penggunaan model pembelajaran kooperatif tipe kartu arisan terhadap hasil belajar siswa di SMA Negeri 8 Palembang tahun pelajaran 2019/2020, maka besar tingkat interprestasi pengaruh adalah $27,6 \%$ dengan kategori "Rendah". Sedangkan koefisien korelasi sebesar $52 \%$ pada kriteria sedang.

Berdasarkan dari hasil penelitian, maka peneliti menyarankan bahwa:

1. Bagi sekolah yaitu hasil penelitian ini untuk meningkatkan kualitas proses pembelajaran dalam mata pelajaran ekonomi sehingga diharapkan dapat mengembangkan model pembelajaran yang baik. Serta meningkatkan standar mutu pembelajaran ekonomi disekolah.

2. Bagi guru yaitu sebagai referensi agar mempertimbangkan penggunaan model pembelajaran kooperatif tipe katu arisan pada mata pelajaran ekonomi. Penerapan model ini sangat efektif, menyenangkan, dan berdampak positif bagi siswa dalam meningkatkan hasil belajar. hasil penelitian ini guru dapat menerapkan model pembelajaran kooperatif tipe kartu arisan dalam meningkatkan kemampuan berfikir kreatif siswa pada mata pelajaran ekonomi.

3. Bagi siswa yaitu menumbuhkan minat dan motivasi belajar siswa pada mata pelajaran ekonomidengan menggunakan model pembelajaran kooperatif tipe kartu arisan sehingga siswa dapat aktif dalam kegiatan pembelajaran.

4. Bagi peneliti yaitu hasil penelitian ini diharapkan dapat menambah wawasan pengetahuan khususnya tentang pengaruh model pembelajaran kooperatif tipe kartu arisan terhadap hasl belajar siswa kelas $\mathrm{X}$ pada mata pelajaran ekonomi di SMA Negeri 8 Palembang Tahun Pelajaran 2019/2020.

\section{DAFTAR PUSTAKA}

Alma. (2012). Guru Profesional Menguasai Metode Dan Terampil Mengajar. Bandung: CV Alfabeta.

Cruickshank, d. (2014). Perilaku Mengajar . Jakarta: Salemba Humanika.

Ernayetti. (2018). Penerapan Model Pembelajaran Kartu Arisan dapat Meningkatkan Hasil Belajar Peserta Didik Pada Pokok Bahasan Program Linier Di Kelas XI MIA 2 SMA Negeri 2 Pekanbaru. Jurnal Pendidikan Ekonomi Akuntansi FKIP UIR. (Online). Volume 6 Nomor 1. (http://journal.uir.ac.id/index.p 
hp/Peka/acticle/view/1865)

(Diakses Kamis, 13 Maret 2019 22:20 WIB).

Gunawan, H. (2017). Implementasi Mata Kuliah Akuntansi manajemen Sebgai. Jurnal Neraca. (http://jurnal.univpgripalembang.ac.id) (Diakses Rabu, 06 November 2019 16:50 WIB).

Hamdayama, J. (2014). Model dan Metode Pembelajaran Kreatif dan Berkarakter. Bogor: Ghalia Indonesia.

Hariyanti, F. (2015). Pembelajaran Kooperatif dengan Teknik Kartu Arisan pada Materi Barisan dan Deret Aritmatika di Kelas XI-APK SMK Negeri 3 Bangkalan. Jurnal Apotema, Volume 1 Nomor2, 87. (Online).

(http://seminar.uny.ac.id/semna smatematika/sites/seminar.uny. ac.id.semnasmatematika/files/P M-52.pdf) (Diakses Rabu, 13 Maret 2019 16:09 WIB).

Irawan, Luluk Dkk. (2019). Pengaruh Media Pembelajaran Komik Terhadap Hasil Belajar Siswa Akuntansi Di Smk Pgri 1 Palembang. Jurnal Neraca: Jurnal Pendidikan dan Ilmu Ekonomi Akuntansi. Vol.3 No.1 (2019) hal. 99-107. DOI: http://dx.doi.org/10.31851/nera ca.v3i1.3385.

Januardi, (2019). Pengaruh Model Think pair share terhadap hasil belajar.

(http://journal2.um.ac.id/index. php/jpe/index) (Diakses Jum'at, 08 November 2019 13:18 WIB)
Jihad, H. (2013). Evaluasi Pembelajaran. Yogyakarta: Multi Presindo.

Malalina. (2018). Model Kooperatif Tipe Kertu Arisan dalam Materi Belah Ketupat dan Layang-Layang. Prosiding Seminar Nasional Etnomatnesia, 845. FKIP Universitas Taman Siswa Palembang. (Online). (http://www.jurnal.ustjogja.ac.i d/index.php/etnomatnesia/articl e/view/2427) (Diakses Rabu, 13 Maret 2019 22:39 WIB)

Pramika, Depi Dan Merlyn Widalismana. (2018). Buku Saku Sebagai Media Pembelajaran Matematika Ekonomi di Program Studi Pendidikan Akuntansi FKIP Universitas PGRI Palembang. PROMOSI: Jurnal Program Studi Pendidikan Ekonomi. Vol 6, No 2 (2018) hal. 1-12. Https://Www.Ojs.Fkip.Ummetr o.Ac.Id/Index.Php/Ekonomi/Ar ticle/View/1685. (Diakses Rabu, 06 November 2019 17:31 WIB).

Pertiwi, F. (2019). Pengaruh Model Pembelajaran Cooperative Script Terhadap Hasil Belajar Siswa Pada Mata Pelajaran Ekonomi Di SMA Negeri 5 Palembang Tahun Pelajaran 2018/2019. Palembang .

Pratiwi, N. (2018). Meningkatkan Hasil Belajar Siswa Melalui Metode Investigasi Kelompok. Prosiding Seminar Nasional Program Pascasarjana (PPS) Universitas PGRI Palembang. https://jurnal.univpgripalembang.ac.id/index.php/Pro sidingpps/article/view/1828/0. 
(Diakses Rabu, 06 Novemer 2019 16:50 WIB)

Priansa. (2015). Manajemen Peserta Didik dan Model Pembelajaran. Bandung: CV Alfabeta.

November 2019.

Ricki Maulizar Sahputra, d. (2017).

Penerapan

Model

Pembelajaran Kooperatif Tipe Kartu Arisan Untuk Meningkatkan Hasil Belajar Siswa Kelas XI IS SMA Negeri 7 Banda Aceh. Jurnal Ilmiah Mahasiswa Pendidikan Geografi FKIP Unsyiah. (Online). Volume 2 Nomor 2. (https://www.neliti.com/id/publ ications/188075). (Diakses Kamis, 17 Januari 2019 13:56 WIB)

Sugiyono. (2011). Metode Penelitian Pendidikan Pendekatan Kuantitatif, Kualitatif, dan R\&D. Bandung: CV Alfabeta.

Suprijono. (2013). Cooperative Learning. Yogyakarta: Pustaka Belajar.

Trianto. (2011). Model Pembelajaran Terpadu Bandung: CV Alfabeta.

Yulaini, E. (2017). Implementasi Model Pembelajaran Make A Match Dalam Pembelajaran Akuntansi. Prosiding Seminar Pendidikan Nasional, 876. FKIP Universitas PGRI Palembang. (Online). (http://jurnal.univpgripalembang.ac.id/index.php/pro siding/article/download/1065) (Diakses Jum'at, 11 Oktober 2019 07:51 WIB) 